\title{
Haemostatic Failure in Babies with Rhesus Isoimmunization
}

\author{
JUDITH M. CHESSELLS and J. S. WIGGLESWORTH \\ From the Neonatal Research Unit, Institute of Child Health and Department of Haematology, Royal Postgraduate \\ Medical School, Hammersmith Hospital, London
}

Chessells, Judith M., and Wigglesworth, J. S. (1971). Archives of Disease in Childhood, 46, 37. Haemostatic failure in babies with rhesus isoimmunization. Platelet counts, fibrinogen levels, thrombotest, thromboplastin generation screening test, thrombin ratio, and titre of circulating fibrin degradation products, were measured in 30 infants with $\mathrm{Rh}$ isoimmunization, of whom 5 had a bleeding tendency clinically, and $\mathbf{8}$ had laboratory evidence of disturbed haemostasis.

At necropsy intravascular fibrin deposits were found in the tissues of 3 out of 4 babies who died with haemorrhage.

An additional retrospective survey indicated that haemorrhage had been a major factor in causing death in 10 out of 18 newborn babies who died with rhesus isoimmunization in the period 1967-69.

Sites of haemorrhage at necropsy were mainly intracranial (subarachnoid and intracerebral) and intrapulmonary, with microscopical evidence of intravascular fibrin deposits in 5 cases.

It is concluded that disseminated intravascular coagulation is a major cause of haemostatic failure in babies with rhesus isoimmunization, but that disturbed hepatic synthesis of coagulation factors may also play a part.

Babies at risk from haemostatic failure are those with cord $\mathrm{Hb}$ below $7 \mathrm{~g} / 100 \mathrm{ml}$. It is suggested that a platelet count should be performed as an initial investigation on all such infants.

A haemorrhagic diathesis is a well-recognized complication of severe erythroblastosis fetalis. A bleeding tendency has been noted in about one-third of fatal cases (Javert, 1942; Leonard, 1945), and haemorrhage has remained a problem since the advent of exchange transfusion (Diamond et al., 1952). Van Praagh (1961), reviewing experiences in Boston over the period 1950-56, found a high incidence of bleeding and stressed the need for inquiry into this problem. The more recent development of intrauterine transfusion (Liley, 1963), while it has improved the prognosis of a small number of severely affected infants, has not been attended, in our experience, by a reduction in the incidence of haemorrhage.

Haemorrhage in the sick rhesus baby could occur in a number of different ways. Bleeding might occur as a consequence of thrombocytopenia, resulting either from marrow depression or from destruction of platelets on an immunological basis.

Received 9 June 1970.
Haemorrhage in these infants could also result from lack of coagulation factors. It is possible that liver function may be impaired in the sick rhesus affected infant, and synthesis of coagulation factors is impaired by hepatic dysfunction (Rapaport et al., 1960). Haemorrhage might also occur because of depletion of clotting factors and platelets as a consequence of disseminated intravascular coagulation.

The present study was undertaken in an attempt to define the mechanisms of haemostatic failure in the rhesus affected infant.

\section{Material and Methods}

The infants studied in the series were all admitted to the neonatal ward at the Hammersmith Hospital during the period 1967-70. All were affected by rhesus isoimmunization as evidenced by the presence of maternal antibodies, and a positive direct Coombs test on the infants' cord blood. The findings in two groups of infants are reported. We first studied 30 consecutive cases of haemolytic disease in newborn infants admitted from the beginning of 1969. 8 of these infants died, and 
of these $\mathbf{7}$ had necropsies, with histological examination of the tissues; in one instance permission for necropsy was refused. Prompted by our findings in these cases we then reviewed the necropsy and histological findings in a second series of rhesus affected babies who had died between January 1967 and December 1968.

Blood for coagulation studies and platelet counts was taken before exchange transfusion from a recently inserted umbilical venous catheter or, in 2 cases, a peripheral vein. Samples were taken into $3.2 \% \mathrm{Na}$ citrate with the addition of one-tenth volume of $10 \%$ $\epsilon$-amino-caproic acid to those intended for estimation of fibrinogen and fibrin degradation products.

Haemoglobin, platelet counts, and coagulation factors were measured by the methods described by Dacie and Lewis (1968). The thromboplastin generation screening test was used as an overall screening test of the intrinsic coagulation mechanism, and the clotting time after 6 minutes' incubation was recorded. The Thrombotest was used as a screening test for the vitamin $\mathrm{K}$-dependent coagulation factors. Plasma fibrinogen was measured by the method of Ratnoff and Menzie (1951), and fibrin degradation products were estimated on thrombin treated plasma by the method of Merskey, Lalezari, and Johnson (1969). If fibrin degradation products were found, the sample was retested at least once. Bilirubin was estimated by a spectrophotometric method.

Histological sections were stained with phosphotungstic acid haematoxylin (Lieb, 1948) and examined for the presence of fibrin thrombi.

\section{Illustrative Case Reports}

We have chosen the histories of 3 babies included in our series. All were severely affected by rhesus isoimmunization with cord $\mathrm{Hb}$ below $7 \mathrm{~g} / 100 \mathrm{ml}$, and all had clinical or laboratory evidence of disturbed haemostasis. Each presented a different clinical problem.

Baby J. Mrs. J., aged 24, had previously had one liveborn unaffected child and one miscarriage. Amniocentesis during her third pregnancy indicated a severely affected infant, and she was referred to Hammersmith Hospital at 33 weeks' gestation for intrauterine transfusion. 3 days after this was performed she went into premature labour. Baby J., weight $3 \mathrm{~kg}$, was pale, apnoeic and oedematous at birth with a heart rate of 60 per minute. His abdomen was distended and there was obvious hepatosplenomegaly. He was intubated and given intermittent positive pressure ventilation. Umbilical arterial and venous catheters were inserted. His $\mathrm{PaO}_{2}$ was only $35 \mathrm{~mm} \mathrm{Hg}$ with a $\mathrm{pH}$ of 6.98 . The cord $\mathrm{Hb}$ was only $3.4 \mathrm{~g} / 100 \mathrm{ml}$, and the bilirubin $4.5 \mathrm{mg} /$ $100 \mathrm{ml}$, all of which gave an indirect reaction. A partial exchange transfusion was performed using fresh heparinized group $\mathrm{O}, \mathrm{Rh}$ negative blood. The infant became hypoglycaemic and was unable to maintain spontaneous regular respirations. Bleeding occurred from the lungs, umbilicus, and heelpricks; intracranial haemorrhage was suspected and he died aged 22 hours.

At necropsy there was a massive subarachnoid haemor- rhage with infarction of the underlying brain, massive pulmonary haemorrhage, and, at microscopical level, disseminated fibrin within the liver and adrenals.

Comment. The clinical picture and histological findings in this baby suggest that haemostatic failure occurred as a consequence of disseminated intravascular coagulation.

Baby S. (Case 12). Mrs. S. had previously had two early neonatal deaths due to rhesus isoimmunization. In this pregnancy amniocentesis suggested a severely affected infant and two intrauterine transfusions were performed. Baby S., born at 32 weeks, weight 2,740 g, was apnoeic and grossly hydropic, with hepatosplenomegaly. Despite active resuscitation and partial exchange transfusion with fresh heparinized blood the infant died at 3 hours of age. The sample of blood taken before exchange transfusion showed the following results : $\mathrm{Hb} 6.6 \mathrm{~g} / 100 \mathrm{ml}$; on Kleihauer stain $92 \%$ of the cells contained adult $\mathrm{Hb}$; bilirubin $7.5 \mathrm{mg} / 100 \mathrm{ml}$ total, $4.0 \mathrm{mg}$ indirect; platelet count $19,000 / \mathrm{mm}^{3}$; plasma fibrinogen $90 \mathrm{mg} / 100 \mathrm{ml}$; ; thrombin-fibrinogen ratio 3; thrombotest under 5\%; thromboplastin generation screening test 37 seconds; factor V $54 \%$ and factor VIII $450 \%$; plasma $\mathrm{Hb} 8.0 \mathrm{mg} / 100 \mathrm{ml}$. Fibrin degradation products were not detected.

At necropsy the infant was grossly hydropic with hepatosplenomegaly. There was no evidence of haemorrhage and sections of internal organs showed no evidence of fibrin deposition.

Comment. In this infant the low vitamin $\mathrm{K}$-dependent factors, as assessed by the thrombotest and the thromboplastin generation screening test, were accompanied by thrombocytopenia and a low plasma fibrinogen, but fibrin degradation products were not detected. These findings, together with the absence of fibrin in the tissues, therefore cannot be explained on a basis of disseminated intravascular coagulation. The severe depression of liver-dependent factors, together with the low fibrinogen and high factor VIII, is more consistent with liver damage. This, of course, does not explain the thrombocytopenia, which might in theory be due to marrow depression as a consequence of intrauterine transfusion (unfortunately, marrow samples were not available for examination).

Baby N. (Case 6). Mrs. N. had had one previous liveborn unaffected child and one stillbirth at 36 weeks. Amniocentesis suggested that this baby was severely affected, and the mother was transferred to this hospital and an elective caesarean section performed at $33 \frac{1}{2}$ weeks. The baby, weight $2,210 \mathrm{~g}$, was pale and apnoeic at birth with a heart rate of 80 per minute, and was intubated and given intermittent positive pressure ventilation. Cord blood findings confirmed the severity of the immunization; $\mathrm{Hb}$ was $4.0 \mathrm{~g} / 100 \mathrm{ml}$; Kleihauer stain showed $96 \%$ of cells contained fetal $\mathrm{Hb}$, with scanty platelets on the film; bilirubin $3.0 \mathrm{mg} / 100 \mathrm{ml}$ all indirect reacting; plasma fibrinogen $131 \mathrm{mg} / 100 \mathrm{ml}$; and fibrin degradation products were present in a titre of 1 in 4. A sample taken before exchange transfusion 
TABLE I

Haemorrhage in Babies with Fatal Rhesus Isoimmunization

\begin{tabular}{|c|c|c|c|c|c|c|c|c|}
\hline \multirow{2}{*}{\multicolumn{2}{|c|}{ Antemortem Haemorrhage }} & \multirow{2}{*}{\multicolumn{2}{|c|}{ No. Necropsied }} & \multirow{2}{*}{$\begin{array}{l}\text { Haemorrhage } \\
\text { at Necropsy }\end{array}$} & \multicolumn{4}{|c|}{ Type of Haemorrhage at Necropsy } \\
\hline & & & & & $\begin{array}{c}\text { Major } \\
\text { Intra-Cranial }\end{array}$ & $\begin{array}{c}\text { Minor } \\
\text { Intra-Cranial }\end{array}$ & $\begin{array}{c}\text { Major } \\
\text { Pulmonary }\end{array}$ & $\begin{array}{c}\text { Minor } \\
\text { Pulmonary }\end{array}$ \\
\hline $\begin{array}{l}\text { Present in } 7 \text { babies } \\
\text { Not present in } 11 \text { babies }\end{array}$ & $\begin{array}{l}\cdots \\
\cdots\end{array}$ & & $\begin{array}{r}6 \\
11\end{array}$ & $\begin{array}{l}6 \\
8\end{array}$ & $\begin{array}{l}6 \\
3\end{array}$ & $\overline{2}$ & $\begin{array}{l}4 \\
1\end{array}$ & $\begin{array}{l}1 \\
5\end{array}$ \\
\hline
\end{tabular}

at 45 minutes of age showed a platelet count of 77,000/ $\mathrm{mm}^{3}$ plasma fibrinogen $124 \mathrm{mg} / 100 \mathrm{ml}$; thrombin ratio 1.5; thrombotest $21.5 \%$; factor V $8 \%$; factor VIII $100 \%$; thromboplastin generation screening test $22 \mathrm{sec}$; and fibrin degradation products were present in a titre of 1 in 8 . He was digitalized and given diuretics; an exchange transfusion, performed with fresh heparinized blood, raised $\mathrm{Hb}$ from 4.4 to $10.4 \mathrm{~g} / 100 \mathrm{ml}$. Progress was complicated by hypoglycaemia and pulmonary oedema, but he improved slowly and no bleeding tendency was observed despite the thrombocytopenia. The titre of fibrin degradation products fell after the first exchange but rose again to 1 in 8 before the second exchange, when the plasma fibrinogen was only $67 \mathrm{mg}$ / $100 \mathrm{ml}$. The second exchange transfusion, performed to raise the $\mathrm{Hb}$ level, was well tolerated; he continued to improve steadily and was discharged home after 6 weeks in hospital.

Comment. In this baby the thrombocytopenia before exchange transfusion was accompanied by a low plasma fibrinogen, low factor $\mathrm{V}$, and the presence of fibrin degradation products. Though reduction of the coagulation factors could be ascribed to liver damage in a sick infant, the relatively normal thrombotest, and the presence of fibrin degradation products, suggest that the thrombocytopenia was a manifestation of disseminated intravascular coagulation.

\section{Results}

These are discussed under three headings: clinical, laboratory, and necropsy findings.
Clinical extent of problem (Table I). During the period 1967 onwards 18 infants died with proven rhesus isoimmunization. 7 of the 18 had generalized antemortem bleeding from heelpricks, umbilicus, and lungs, and intracranial haemorrhage was suspected because of failure to establish regular respirations or because of apnoeic attacks. In the 6 babies in this group who had necropsy the diagnosis of intracranial haemorrhage was confirmed and was of an unusual variety which we discuss later. In 3 further infants, who had no haemorrhagic symptoms during life, similar massive intracranial haemorrhage was found at necropsy, and was associated with massive pulmonary haemorrhage in one infant. In 5 infants focal alveolar haemorrhage was found; one of the 5 babies had kernicterus and two had small subarachnoid haemorrhages. In 3 infants there was no evidence of bleeding. Thus in at least 10 of these babies bleeding was a major factor in causing death.

Laboratory findings. The results of these, available in 30 babies, were obtained on samples taken before the first exchange transfusion and were incomplete in some cases. Table II shows the range of results obtained in babies who were severely affected (cord $\mathrm{Hb} 7 \mathrm{~g} / 100 \mathrm{ml}$ or less) compared to the remainder.

TABLE II

Laboratory Results in 30 Babies with Rhesus Isoimmunization

\begin{tabular}{|c|c|c|c|c|c|c|c|c|c|c|c|c|}
\hline \multirow{2}{*}{$\begin{array}{r}\text { Cord Hb } \\
(\mathrm{g} / 100 \mathrm{ml})\end{array}$} & \multirow{2}{*}{$\begin{array}{l}\text { Intrauterine } \\
\text { Transfusion }\end{array}$} & \multicolumn{2}{|c|}{$\begin{array}{l}\text { Platelets } \\
10^{3} / \mathrm{mm}^{3}\end{array}$} & \multirow{2}{*}{$\begin{array}{l}\text { FDP } \\
\text { Present }\end{array}$} & \multicolumn{2}{|c|}{$\begin{array}{c}\text { Fibrinogen } \\
(\mathrm{mg} / 100 \mathrm{ml})\end{array}$} & \multicolumn{2}{|c|}{$\begin{array}{c}\text { Thrombotest } \\
(\%)\end{array}$} & \multicolumn{2}{|c|}{$\begin{array}{l}\text { Thromboplastin } \\
\text { Screening Test } \\
\text { (sec) }\end{array}$} & \multicolumn{2}{|c|}{$\begin{array}{c}\text { Thrombin } \\
\text { Ratio }\end{array}$} \\
\hline & & Range & $\begin{array}{l}\text { No. } \\
<100\end{array}$ & & Range & $\begin{array}{l}\text { No. } \\
<100\end{array}$ & Range & $\begin{array}{l}\text { No. } \\
<10\end{array}$ & Range & $\begin{array}{l}\text { No. } \\
>20\end{array}$ & Range & $\begin{array}{l}\text { No. } \\
>2\end{array}$ \\
\hline $\begin{array}{l}>7 \\
(19)^{\star}\end{array}$ & $\begin{array}{c}4 \\
(19)\end{array}$ & $\begin{array}{l}167- \\
376\end{array}$ & $\begin{array}{c}0 \\
(18)\end{array}$ & $\begin{array}{c}5 \\
(18)\end{array}$ & $\begin{array}{l}122- \\
366\end{array}$ & $\begin{array}{c}0 \\
(18)\end{array}$ & $11 \cdot 5-46$ & $\begin{array}{c}0 \\
(17)\end{array}$ & $8-32$ & $\begin{array}{c}1 \\
(17)\end{array}$ & $0 \cdot 6-2 \cdot 8$ & $\begin{array}{c}1 \\
(17)\end{array}$ \\
\hline $\begin{array}{l}<7 \\
(11)\end{array}$ & $\begin{array}{c}5 \\
(11)\end{array}$ & $\begin{array}{l}19- \\
283\end{array}$ & $\begin{array}{c}5 \\
(10)\end{array}$ & $\begin{array}{c}6 \\
\text { (11) }\end{array}$ & $\begin{array}{l}60- \\
358\end{array}$ & $\begin{array}{c}2 \\
(8)\end{array}$ & $5-30$ & $\begin{array}{c}2 \\
(8)\end{array}$ & $14-37$ & $\begin{array}{r}\mathbf{4} \\
(7)\end{array}$ & $1 \cdot 3-6$ & $\begin{array}{c}3 \\
(7)\end{array}$ \\
\hline $\begin{array}{l}\text { Differences } \\
\text { between } \\
\text { groups by } \chi^{2}\end{array}$ & NS & - & $p<0.01$ & NS & - & NS & - & NS & - & $p<0.05$ & - & NS \\
\hline
\end{tabular}

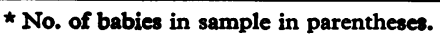


Haemostatic Failure in Babies with Rhesus Isoimmunization

TABLE III

Data on 11 Babies in whom Fibrin Degradation Products were Detected

\begin{tabular}{|c|c|c|c|c|c|}
\hline Case No. & Cord $\mathrm{Hb}(\mathrm{g} / 100 \mathrm{ml})$ & $\begin{array}{l}\text { Intrauterine } \\
\text { Transfusion }\end{array}$ & FDP Titre & $\begin{array}{c}\text { Plasma Fibrinogen } \\
(\mathrm{mg} / 100 \mathrm{ml})\end{array}$ & $\begin{array}{l}\text { Platelets } \\
\left(10^{3} / \mathrm{mm}^{3}\right)\end{array}$ \\
\hline $\begin{array}{r}1 \\
2 \\
3 \\
4 \\
5 \\
6 \\
7 \\
8 \\
9 \\
10 \\
11\end{array}$ & $\begin{array}{c}4 \cdot 8 \\
10 \cdot 1 \\
6 \cdot 8 \\
8 \\
12 \cdot 6 \\
4 \cdot 1 \\
5 \\
3 \\
5 \\
7 \cdot 7 \\
14\end{array}$ & $\begin{array}{l}\text { Yes } \\
\text { Yes } \\
\text { Yes } \\
\text { Yes } \\
\text { Yes } \\
\text { No } \\
\text { No } \\
\text { No } \\
\text { No } \\
\text { No } \\
\text { No }\end{array}$ & $\begin{array}{r}4 \\
2 \\
4 \\
16 \\
2 \\
8 \\
4 \\
4 \\
2 \\
2 \\
\text { Undiluted Serum }\end{array}$ & $\begin{array}{r}358 \\
140 \\
120 \\
134 \\
124 \\
60 \\
209 \\
148 \\
122 \\
223\end{array}$ & $\begin{array}{r}158 \\
263 \\
- \\
194 \\
77 \\
32 \\
33 \\
14 \\
213 \\
281\end{array}$ \\
\hline
\end{tabular}

Platelet counts. These were performed on 28 out of 30 infants and were within the normal range in 23 babies and under $100,000 \mathrm{~mm}^{3}$ in 5 infants. 4 of the thrombocytopenic babies died, as opposed to 3 of the non-thrombocytopenic group. 9 of these babies had been given intrauterine transfusions; platelets counts were performed on 7 of these; 6 were normal and one was very low $\left(19,000 \mathrm{~mm}^{3}\right)$. All the thrombocytopenic babies had cord $\mathrm{Hb}$ below $7 \mathrm{~g} / 100 \mathrm{ml}$.

Plasma fibrinogen. This was under $100 \mathrm{mg} / 100$ $\mathrm{ml}$ in 2 babies, both of whom were thrombocytopenic. The other babies with low platelet counts had fibrinogen in excess of $124 \mathrm{mg} / 100 \mathrm{ml}$.

Thrombin-fibrinogen time. This is prolonged in the normal newborn and may be twice that of the adult normal. This was found in 4 babies out of 24, 2 of whom were thrombocytopenic.

Thrombotest. This test, which reflects the level of the vitamin $\mathrm{K}$-dependent coagulation factors, is variably depressed in the newborn infant. In this group of babies a thrombotest of $10 \%$ or under was only found in 2 babies, both with $\mathrm{Hb}$ levels below $7 \mathrm{~g} / 100 \mathrm{ml}$.

Thromboplastin generation screening test (TGST).
This screening test of the intrinsic coagulation system is influenced by deficiencies of factors $V$ and VIII as well as the vitamin $\mathrm{K}$-dependent factors IX and X. Results of the test in the newborn may be variably prolonged beyond the normal adult range of 7-11 sec. Values above $20 \mathrm{sec}$ were found in 5 babies, 3 of whom were thrombocytopenic.

Fibrin degradation products (FDP). These were detected in 11 of the 29 babies in whom the estimation was performed (Table III). These included 4 of the 5 thrombocytopenic babies, one baby in whom a platelet count was not performed (he died after extensive bleeding), and 5 babies with a normal platelet count. This group of babies with FDP included 5 out of the 9 babies who had been given intrauterine transfusion, and 6 out of 11 with $\mathrm{Hb}$ under $7 \mathrm{~g}$. The titre in which FDP were found ranged from 1 in 16 in a baby with haemostatic failure, to undiluted serum in a baby who had no other evidence of abnormal haemostasis.

Babies with disturbed haemostasis. Table IV shows the results on 8 babies who had evidence of disturbed haemostasis as evidenced by one or more of the following: thrombocytopenia, plasma fibrinogen under $100 \mathrm{mg} / 100 \mathrm{ml}$, Thrombotest of $10 \%$

TABLE IV

Results on 8 Babies with Disturbed Haemostasis

\begin{tabular}{|c|c|c|c|c|c|c|c|c|}
\hline Case No. & $\begin{array}{l}\text { Cord Hb } \\
(\mathrm{g} / 100 \mathrm{ml})\end{array}$ & $\begin{array}{l}\text { Cord Bilirubin } \\
\text { Total/Indirect }\end{array}$ & $\begin{array}{c}\text { Platelets } \\
\left(10^{3} / \mathrm{mm}^{3}\right)\end{array}$ & $\begin{array}{c}\text { Fibrinogen } \\
(\mathrm{mg} / 100 \mathrm{ml})\end{array}$ & $\begin{array}{l}\text { Thrombin } \\
\text { Fibrinogen }\end{array}$ & $\begin{array}{l}\text { FDP } \\
\text { Titre }\end{array}$ & $\begin{array}{c}\text { Thrombotest } \\
(\%)\end{array}$ & $\begin{array}{c}\text { Thromboplastin } \\
\text { Generation } \\
\text { Screening Test } \\
\text { (sec) }\end{array}$ \\
\hline $\begin{array}{r}5 \\
6 \\
7 \\
8 \\
9 \\
12 \\
13 \\
14\end{array}$ & $\begin{array}{r}12 \cdot 6 \\
4 \cdot 1 \\
5 \cdot 0 \\
3 \cdot 0 \\
5 \cdot 0 \\
6 \cdot 6 \\
6 \cdot 6 \\
6 \cdot 3\end{array}$ & $\begin{array}{c}6 \cdot 0 / 5 \cdot 5 \\
3 \cdot 0 / 3 \cdot 0 \\
6 \cdot 0 / 3 \cdot 0 \\
6 \cdot 0 / 4 \cdot 5 \\
5 \cdot 9 \\
7 \cdot 5 / 4 \cdot 0 \\
8 \cdot 5 / 7 \cdot 5 \\
5 \cdot 0 / 4 \cdot 5\end{array}$ & $\begin{array}{r}194 \\
77 \\
32 \\
33 \\
14 \\
19 \\
230 \\
252\end{array}$ & $\begin{array}{r}134 \\
124 \\
60 \\
209 \\
148 \\
90 \\
234 \\
134\end{array}$ & $\begin{array}{l}2 \\
1 \cdot 5 \\
1 \cdot 9 \\
>6 \\
3 \\
2 \cdot 8 \\
1 \cdot 3\end{array}$ & $\begin{array}{l}2 \\
8 \\
2 \\
4 \\
2 \\
0 \\
0 \\
0\end{array}$ & $\begin{array}{c}18 \\
21 \cdot 5 \\
19 \cdot 5 \\
25 \\
12 \\
<5 \\
10 \\
30\end{array}$ & $\begin{array}{l}32 \\
22 \\
22 \\
16 \\
37 \\
17 \\
25\end{array}$ \\
\hline
\end{tabular}


or less, or TGST greater than $20 \mathrm{sec}$. In Cases 6 to 9 , thrombocytopenia was accompanied by the presence of FDP, a low or low normal plasma fibrinogen in 2 cases, and a prolongation of the TGST beyond $20 \mathrm{sec}$ in 2 cases. These findings are suggestive of disseminated intravascular coagulation. Case 6 (Baby $N$ ) survived, but babies 7 to 9 died of bleeding. Case 5 showed no evidence of disturbed haemostasis apart from a prolonged TGST and the presence of FDP, but later died of intracranial haemorrhage. Case 12 (Baby S) was hydropic and died without evidence of bleeding. Cases 13 and 14, with normal platelet counts but low screening tests for deficiency of coagulation factors, remained well and did not bleed. Bonemarrow in Cases 5 and 8 showed plentiful megakaryocytes.

Necropsy findings (Table V). Of the babies on whom laboratory studies had been performed, necropsy studies confirmed the presence of intracranial haemorrhage in 4 of the 5 who had died of bleeding (Cases 4, 5, 8, and 9). In 3 of these infants (Cases 5, 8, and 9) disseminated fibrin was

\section{TABLE V}

Necropsy Findings in 17 Babies with Rhesus Isoimmunization

\begin{tabular}{c|c|c|c|c|c}
\hline $\begin{array}{c}\text { Macroscopical } \\
\text { Findings at } \\
\text { Necropsy }\end{array}$ & $\begin{array}{c}\text { No. } \\
\text { with } \\
\text { Fibrin }\end{array}$ & \multicolumn{2}{|c|}{ Site of Fibrin Deposition } \\
\hline $\begin{array}{c}\text { Intracranial } \\
\text { haemorrhage } \\
\text { (9 babies) }\end{array}$ & 8 & 7 & 5 & 1 & - \\
$\begin{array}{c}\text { No intracranial } \\
\text { haemorrhage } \\
\text { (8 babies) }\end{array}$ & 1 & - & 1 & - & - \\
\hline
\end{tabular}

found in the liver or adrenals. Fibrin thrombi were also found in the adrenal sinusoids of a hydropic infant who had no evidence of a bleeding tendency and a normal platelet count.

Of the 10 infants who were studied only at necropsy, 4 had subarachnoid or intracranial haemorrhage in association with haemorrhage into the lungs, one had subarachnoid and intracerebellar haemorrhage without pulmonary haemorrhage, and one had haemorrhage and oedema of the lungs only. Microscopical studies revealed fibrin thrombi within hepatic or adrenal sinusoids of all 5 infants with intracranial haemorrhage.

The intracranial haemorrhage seen in these babies consisted of a well-defined clot within the subarachnoid space often compressing or infiltrating the underlying cortex. This might be situated over part of one cerebral hemisphere as illustrated previously (Chessells and Wigglesworth, 1970), or there might be one or more haemorrhages over the cerebellar hemispheres. The origin of the haemorrhage was not apparent either at macroscopical or histological level, due to the extent of the clot and the disruption of the leptomeninges which occurs on handling the immature brain. The characteristic sharp localization of the clot suggested that it had probably occurred in many instances at a sub-pial level and was thus a primary intracerebral haemorrhage. No fibrin thrombi were seen on PTAH staining of brain sections from cases with cerebral haemorrhage.

Histological study of the lungs showed widespread alveolar and intrabronchial haemorrhage in 4 instances and focal haemorrhage in 6 others. The haemorrhage characteristically affected the airspaces and bronchi, but minor interstitial haemorrhages might also be present. 5 of the cases with pulmonary haemorrhages showed hyaline membrane formation. On PTAH staining much of the hyaline material was seen to consist of fibrin, and additional masses of fibrin were demonstrated within the airways. In 4 cases the lungs showed hyaline membrane disease without haemorrhage, and in these sections there was very little PTAH-positive material associated with the membranes.

Intravascular fibrin deposits were accepted as ante mortem in origin if they were in the form of solid fibrin thrombi occluding the sinusoids of the liver or adrenals, or presented the streaming appearance in larger vessels described by Boyd (1967). In one instance (Case 8), fibrin thrombi in the liver were associated with small areas of hepatic necrosis, and in another there were similar small areas of necrosis in the adrenals. Fibrin deposition within the small arteries and pulp of the spleen was seen in one case, and fibrin deposits over the surface of the spleen in two cases, both of which had been subjected to intrauterine transfusion.

Other organs, including kidney, myocardium, pancreas, thymus, thyroid, pituitary, and submandibular gland were examined but showed no evidence of intravascular fibrin deposition. Sections of bone-marrow showed no reduction in the number of megakaryocytes.

\section{Discussion}

Previous investigations. Several groups of workers have studied the mechanism of haemostatic failure in babies with rhesus isoimmunization. Heyn et al. (1952) measured platelets and screened coagulation factors, while Engström and Kager (1961) measured plasma fibrinogen, but neither group found any difference between the normal and 
rhesus-immunized infant. More recently (1967), Ekert and Mathew reported occasional low platelet counts in rhesus-immunized infants, and this finding has been confirmed by Nielsen (1970). However, none of these studies included babies with clinical evidence of haemostatic failure.

Our results. The present series of babies includes several with obvious haemostatic failure. Our clinical findings confirm that bleeding remains an important complication of this disease and occurs in the more severely affected infants. Haemorrhage is most commonly intracranial, but is often accompanied by bleeding into the lungs and oozing from umbilicus and injection sites.

The laboratory results point to at least two mechanisms whereby haemostatic failure might occur in the sick rhesus baby. First (Cases 6, 7, 8, and 9), there is strong evidence that haemostatic failure may occur in association with disseminated intravascular coagulation (DIC). The laboratory evidence for this: thrombocytopenia, low plasma fibrinogen levels, abnormal screening tests for factors $V$ and VIII, and presence of circulating FDP is supported by the demonstration of intravascular fibrin in the tissues of those babies with a haemorrhagic diathesis who came to necropsy.

In our cases and those of other workers (Hathaway, Mull, and Pechet, 1969), there is often a discrepancy between the extent of the haemostatic defect and the amount and distribution of fibrin deposition. Necropsy material is by no means ideal for the detection of fibrin deposits because of the possible occurrence of post-mortem fibrinolysis. The use of immunofluorescent techniques may reveal fibrin deposits which are undetectable by conventional methods such as PTAH staining (Gitlin, Craig, and Janeway, 1957).

We are satisfied that disseminated intravascular coagulation is a common and important cause of haemostatic failure in babies with rhesus isoimmunization.

Secondly, the demonstration of very low plasma vitamin $\mathrm{K}$-dependent factors and fibrinogen in one hydropic baby (Case 12, baby S.) who had no bleeding or fibrin deposition at necropsy suggests that impaired synthesis of coagulation factors might occur as a result of liver failure. Cases 13 and 14 had a low thrombotest and TGST, respectively; in the absence of specific assays, it is not possible to say if this is a reflection of hepatic damage or immaturity or, in Case 14, a reflection of low factors $\mathrm{V}$ and VIII.

Case 5 is of interest because, at birth, apart from the rather prolonged TGST and the presence of
FDP, there was no evidence of disturbed haemostasis. He was thought clinically to have had an intraventricular haemorrhage and succumbed within 12 hours. Despite a normal platelet count and plasma fibrinogen, he was found at necropsy to have not intraventricular but atypical subarachnoid haemorrhage and disseminated intravascular fibrin in the liver.

In those babies in whom bone-marrow sections were available, plentiful megakaryocytes were seen. The fact that this group included 3 babies born after intrauterine transfusion, 2 of whom bled, does not support the hypothesis that production of platelets is depressed as a consequence of intrauterine transfusion. In babies who have not received intrauterine transfusion marrow hypoplasia occurs after the first few days of life (Hurdle and Davis, 1965).

We have not attempted to look for platelet antibodies in these mothers and babies. Though the rhesus antigen is specific to the red cell (Gurevitch and Nelken, 1957) platelet antibody formation might be stimulated by the same mechanism which results in production of rhesus antibody, and platelet destruction might occur on an immunological basis as in isoimmune neonatal thrombocytopenia (Shulman et al., 1964). However, this would not explain the other laboratory and necropsy findings.

If, as we have suggested, the sick rhesus baby is at risk from haemostatic failure as a consequence of DIC, two questions must be answered: first, why should the coagulation mechanism be activated and, secondly, how may this be diagnosed and treated ?

DIC is a known complication of intravascular haemolysis (Hardaway et al., 1956), but the destruction of the red cell by rhesus antibody is extravascular and takes place mainly in the spleen (Jandl, Jones, and Castle, 1957). The plasma haemoglobin was not raised in these babies compared to controls.

Fibrin formed in the vessels is normally cleared by the fibrinolytic system and the reticuloendothelial system. The fibrinolytic system is deficient in infancy (Phillips and Skrodelis, 1958), and recent work suggests that the spleen, functioning as an organ of the reticuloendothelial system, may not be as efficient in the neonate as in the normal adult (Holroyde, Oski, and Gardner, 1969). If this were so, then both pathways for fibrin clearance may be depressed in an infant whose reticuloendothelial system is already under strain. Moreover, work by Bradlow in 1961 indicated that intact red cells and reticulocytes can release material with coagulant properties. It is possible that such material may be released from red cells or their precursors, or 
re-enter the circulation from the spleen, thus activating the coagulation mechanism.

We have pointed out in a previous communication the likely roles of hypothermia and acidosis in exacerbating or initiating haemostatic failure. These factors may, of course, operate in the sick rhesus baby and worsen the prognosis.

Before discussing the question of management, it is important to consider the probable timing of events resulting in haemostatic failure. The behaviour of many babies (for example Baby J.) who have had cerebral haemorrhage suggests that bleeding into the brain is a very early event and is probably the cause of the baby's failure to establish adequate respiration. Yet Case 5, also thought to have cerebral haemorrhage from birth, had two normal platelet counts at this time with little evidence of disturbed haemostasis and, yet, at necropsy, had disseminated fibrin deposits in the liver. This may indicate that DIC occurred later and was unrelated to the cerebral haemorrhage, or may indicate the difficulties of diagnosis of DIC.

Affected infants of mothers with idiopathic thrombocytopenic purpura undergo maximum stress within the first few hours of life, and it is known from the work of Boyd (1966) and the recent report of Moore, McAdams, and Sutherland (1969) that the syndrome of DIC may occur in utero. If this happens, the infant may be thrombocytopenic at birth and at risk from catastrophic intracranial haemorrhage. Yet the infant who may bleed is not always identifiable by a low platelet count at birth.

The problem of management involves detection of the baby at risk. As Diamond et al. pointed out in 1952, the babies at risk of bleeding are those most severely affected by $\mathrm{Rh}$ isoimmunization. Few laboratory tests can be rapidly performed in an emergency to provide immediate help in diagnosis. Of those that are readily available, the thrombotest is insensitive to depletion of those coagulation factors usually consumed in DIC, and we found a low thrombotest in our series only in association with suspected liver dysfunction. The TGST is more helpful, but merely indicates a non-specific disorder of the intrinsic coagulation system. Estimation of the plasma fibrinogen is not usually available in an emergency. The finding of FDP in low titre is not necessarily evidence of disturbed haemostasis. FDP in higher titre have usually been found in more severely affected babies, but their presence may be merely indicative of a collection of blood extravascularly, for example in the cranial or peritoneal cavities.

We feel that the platelet count is probably the most sensitive index that the baby is at risk from haemostatic failure. A count on venous blood may be readily obtained from a cord or umbilical venous sample. If thrombocytopenia is found, the baby is at risk of bleeding. In theory, replacement transfusion with fresh heparinized blood should supply platelets and coagulation factors and could be supplemented where necessary with a simple transfusion of fresh blood or platelets. Unfortunately, it may not always be possible to predict the onset of haemorrhagic symptoms. However, we consider that a platelet count should be included in the initial studies on all severely affected infants.

This work was done while J.M.C. was in receipt of a clinical Research Fellowship from the Medical Research Council. We should like to thank Professor J. P. M. Tizard, Dr. W. R. Pitney, and Mr. H. Gordon for their helpful advice and encouragement. Our thanks are due also to Mrs. B. Burford for technical assistance and to the M.R.C. for a grant for technical assistance to J.S.W.

\section{REFERENCES}

Boyd, J. F. (1966). Disseminated fibrin thrombo-embolism in stillbirths: a histological picture similar to one form of maternal hypofibrinogenaemia. Fournal of Obstetrics and Gynaeiology of the British Commonwealth, 73, 629.

(1967). Disseminated fibrin thromboembolism among neonates dying within $\mathbf{4 8}$ hours of birth. Archives of Disease in Childhood, 42, 401.

Bradlow, B. A. (1961). Liberation of material with platelet-like coagulant properties from intact red cells and particularly from reticulocytes. British fournal of Haematology, 7, 476.

Chessells, J. M., and Wigglesworth, J. S. (1970). Secondary haemorrhagic disease of the newborn. Archives of Disease in Childhood, 45, 539.

Dacie, J. V., and Lewis, S. M. (1968). Practical Haematology, 4th. ed. Churchill, London.

Diamond, L. K., Allen, F. H., Jr., Vann, D. D., and Powers, J. R. (1952). Round table discussion: erythroblastosis fetalis. Pediatrics, 10, 337.

Ekert, H., and Mathew, R. Y. (1967). Platelet counts and plasma fibrinogen levels in erythroblastosis foetalis. Medical fournal of Australia, 2, 844.

Engström, L., and Kager, L. (1961). Concentration of fibrinogen in the plasma of healthy and of erythroblastotic and hyperbilirubinemic newborn infants. Acta Paediatrica, 50, 581.

Gitlin, D., Craig, J. M., and Janeway, C. A. (1957). Studies on the nature of fibrinoid in the collagen diseases. American fournal of Pathology, 33, 55.

Gurevitch, J., and Nelken, D. (1957). Studies on platelet antigens. III. $\mathrm{Rh}-\mathrm{Hr}$ antigens in platelets. Vox Sanguinis, 2, 342.

Hardaway, R. M., III, McKay, D. G., Wahle, G. H., Jr., Tartock, D. E., and Edelstein, R. (1956). Pathological study of intrravascular coagulation following incompatible blood transfusion in dogs. American fournal of Surgery, 81, 24.

Hathaway, W. E., Mull, M. M., and Pechet, G. (1969). Disseminated intravascular coagulation in the newborn. Pediatrics, 43, 233.

Heyn, R. M., Rozenfeld, I. H., Grossman, B. J., and Stuart, J. D. (1952). Coagulation studies in the newborn infant. II. Erythroblastosis fetalis. Pediatrics, 8, 327.

Holroyde, C. P., Oski, F. A., and Gardner, F. H. (1969). The 'pocked' erythrocyte. New England fournal of Medicine, 281, 516.

Hurdle, A. D. F., and Davis, J. A. (1965). The 'late' anaemia of haemolytic disease of the newborn. British fournal of Haemato$\log y, 11,247$.

Jandl, J. H., Jones, A. R., and Castle, W. B. (1957). The destruction of red cells by antibodies in man. I. Observations on the sequestration and lysis of red cells altered by immune mechanisms. Fournal of Clinical Investigation, 36, 1428. 
Javert, C. T. (1942) Erythroblastosis neonatorum. Surgery, Gynaecology and Obstetrics, 74, 1.

Leonard, M. F. (1945). Hemolytic disease of the newborn. Fournal of Pediatrics, 27, 249.

Lieb, E. (1948). Modified phosphotungstic acid-hematoxylin stain. Archives of Pathology, 45, 559.

Liley, A. W. (1963). Intrauterine transfusion of foetus in haemolytic disease. British Medical fournal, 2, 1107.

Merskey, C., Lalezari, P., and Johnson, A. J. (1969). A rapid, simple, sensitive method for measuring fibrinolytic split products in human serum. Proceedings of the Society for Experimental Biology and Medicine, 131, 871.

Moore, C. M., McAdams, A. J., and Sutherland, J. (1969). Intrauterine disseminated intravascular coagulation: a syndrome of multiple pregnancy with a dead twin fetus. Fournal of Pediatrics, 74, 523.

Nielsen, N. C. (1970). Coagulation and fibrinolysis in rhesusimmunized mothers and their erythroblastotic newborn infants. Acta Obstetrica Gynecologica Scandinavica, 49, 61.

Phillips, L. L., and Skrodelis, V. (1958). A comparison of the fibrinolytic enzyme system in maternal and umbilical-cord blood. Pediatrics, 22, 715.

Rapaport, S. I., Ames, S. B., Mikkelsen, S., and Goodman, J. R. (1960). Plasma clotting factors in chronic hepatocellular disease. New England fournal of Medicine, 263, 278.

Ratnoff, O. D., and Menzie, C. (1951). A new method for the determination of fibrinogen in small samples of plasma. fournal of Laboratory and Clinical Medicine, 37, 316.

Shulman, N. R., Marder, V. J., Hiller, M. C. and Collier, E. M. (1964). Platelet and leukocyte isoantigens and their antibodies: serologic, physiologic and clinical studies. Progress in Hematology, 4, 222.

Van Praagh, R. (1961). Causes of death in infants with hemolytic disease of the newborn (erythroblastosis fetalis). Pediatrics, 28, 223.

Correspondence to Dr. J. S. Wigglesworth, Institute of Child Health, Hammersmith Hospital, Du Cane Road, London W.12. 